Journal of Science
http://dergipark.gov.tr/gujs

\title{
Adaptive Architecture Based on Environmental Performance: An Advanced Intelligent Façade (AIF) Module
}

\author{
Erhan KARAKOC ${ }^{1, *(1)}$, Gulen CAGDAS $^{2}$ (i) \\ ${ }^{1}$ ITU Graduate School, Architectural Design Computing Program, ITU Ayazaga Campus, 34496, Maslak, Istanbul, Turkey \\ ${ }^{2}$ ITU Faculty of Architecture, Architecture Department, ITU Taskisla Campus, 34437, Beyoglu, Istanbul, Turkey
}

Highlights

- The classification of adaptive façade and the definition of advanced and intelligent façade.

- An advanced intelligent façade module is developed with a novel decision-making strategy.

- The prototype named AIF module is simulated for the Mediterranean climate.

\begin{tabular}{l} 
Article Info \\
\hline \\
Received: 23 Apr 2020 \\
Accepted:01 Jan 2021 \\
Keywords \\
\hline Adaptive façade \\
Intelligent façade \\
Decision-making system \\
Simulation \\
Prototyping
\end{tabular}

\section{INTRODUCTION}

Adaptation is the ability of the system to change physical values according to multiple parameters, to provide the aimed functional state under changing conditions in terms of design variables [1,2]. Negroponte evaluated the concept of an adaptive environment '...is taking an active role, initiating to a greater or lesser degree changes as a result and function of complex or simple computations...' [3]. In parallel with technological advances, various approaches and concepts have been started to be developed in the field of adaptive architecture.

Adaptive architecture is a contemporary design approach that focuses on the users and contributes to sustainability. There are many studies in which this approach is used, ranging from building envelope to plan-layout arrangement and furniture relocation [4], i.e. from macro to micro scale [5]. This study focused on the façades that are considered as an important layer in the prevention of various conditions brought by weather related changes in the exterior affecting the interior. Although weather conditions vary as daily and seasonal changes, conventional building façades are not capable of responding to these changes due to their static properties [5]. 
The advances in the performance of building elements such as façade and equipment of heating, ventilation, and lighting are caused by the research and technological innovation in the last decade [6]. Thus, adaptive façades are introduced as layers that separate the interior and exterior of buildings, using decision-making systems, smart materials, innovative building details, and other technological approaches based on the sustainability of architecture. They can react continuously to changes in boundary conditions in compliance with the requirements of the effect, performing as a whole with the system i.e. in an integrated manner, according to performance requirements and motivations [7] used for building energy conservation [8]. By optimizing the user comfort [9] and energy consumption of the building, adaptive façade contributes to sustainability [10]. It enables buildings to be dynamic and response efficiently to environmental stimuli [5,6,11]. Therefore, multifunctional adaptive façades should be able to respond continuously [10] and appropriately to the changes in performance requirements and boundary conditions [8] and to meet external and internal changes in climate and user needs [12]. Adaptive façades ensure comfortable and ideal conditions for the user by controlling the environmental factors effectively. In regions where climatic change is constantly experienced, buildings that can adapt to the environment should be designed. Moreover, such façades adapt to existing weather conditions, save energy and help users by responding instantly to their needs and preferences to provide comfortable spaces [5] by changing its functions, features, or behaviors over time according to temporary performance requirements and special weather conditions [13].

Nowadays, more active systems have come to the forefront in the design of façades rather than passive systems due to conventional construction methods and materials. However, active systems are not a preferable approach for many reasons, especially in terms of operating costs and energy consumption effecting the sustainability. Façade system consisting of performance-driven building elements and materials controlled by intelligent systems is proposed as a solution to this problem in the conceptualization phase of façade design. In adaptive mechanisms in the façade, active systems have been used rather than passive technological solutions over the years [14]. Thus, adaptive façades adopt active systems which use the energy produced from renewable energy sources controlled by a building management system defined as intelligence of the building to optimize parameters that are affecting the user comfort and energy consumption. As a sub-category of adaptive façades, advanced and intelligent façades consisting of building management system, environmental data sensors, sensitive artificial lighting, solar and ventilation control elements, user control, and double-layered façade elements are introduced [15]. There is a need for adaptive mechanisms embedded with an intelligence, i.e. decision-making system that can respond the changing conditions by optimizing energy consumption considering recent discussions on adaptive façades, which is shown in below:

- Reducing energy consumption by responding externally changing climatic effects $[5,16]$ with low operating costs compared to active systems due to the recent advances in building technology regarding the ease of applicability of adaptive and dynamic façades ;

- The domination of the market by the conventional static shutters that cannot respond climatic changes [5] in majority of buildings except high-rise building projects [12] ;

- Conflicts in multi-objective optimization in decision-making process between the parameters of the presence and preferences of the user [17] regarding user comfort [9] and energy conservation $[8,18]$;

- Shortened service life due to material fatigue caused by the extensive movement of kinetic façade components by resulting in component failure [19] ;

- Limited research on how to operate the kinetic modules in adaptive façades, which use the sensors and actuators in terms of the use of input data to avoid conflicts that occur in the trade-offs between multiple parameters in the boundary conditions [20-26].

To answer these problems mentioned in literature, it is aimed to develop the Advance Intelligent Façade (AIF) module as a performance-driven adaptive and electromechanical prototype that responds to environmental conditions and to propose critical decision and priority algorithms to incorporate ambient data to solve conflicts in the decision-making process. The AIF module has a multi-layered design 
controlled by advanced algorithms consisting of multi-parameter optimization and prediction algorithms according to statistical data, which is lacking in intelligent façades. The AIF is defined as an advanced intelligent module designed to produce the appropriate response with the help of electromechanical systems by sensing the indoor and outdoor temperature, daylight, and humidity parameters with the help of sensors. The methodology of the paper is to verify the proposed system consisting of electromechanical module and decision-making algorithms via simulation according to four scenarios that is implemented of the weather data of equinox dates in Mediterranean climate. As a result of the performance validation by simulation, it is expected that the AIF module outperforms the static façade in terms of energy efficiency and user comfort in indoor. Producing an intelligent and adaptive façade module based on performative principles has been determined as the primary objective to ensure optimum comfort conditions in interior space. The AIF module, which systematically adapts to various environmental conditions will perpetuate sustainability. AIF module aims to contribute to the building and construction industry as an innovative product.

The discussions will be structured on:

- What are the methods in the design of a performance-driven adaptive façade that is controlled by an intelligent system in the digital and physical environment?

- How can the multi-objective optimization algorithms based on prediction and the Advanced Intelligent Façade (AIF) module can be integrated with hardware and software in a dynamic façade module?

- How can the AIF and embedded decision-making process work effectively in boundary weather conditions or conflicts in this process in terms of the trade-off between the user demand and energy consumption?

The article will be structured under three main sections as background, the module setup and performance validation by simulation. In the background section, it is aimed to clarify the classification of the adaptive façade systems by positioning the AIF module in the literature. In this section, decision making systems, algorithms and parameters of adaptive façades will be examined through case studies. The particular section is devoted to the discussion of the design process and methods of the AIF module in the context of adaptability. Then, the simulation process of proposed system will be presented. The potentials and limitations of the decision-making strategy is put forward as final remarks.

\section{BACKGROUND}

\subsection{The Classification of Adaptive Façades}

Adaptive façade is classified in many types as interactive, responsive, smart, biomimetic, kinetic, advanced and intelligent, by reinterpreting the classification of Romano et al. suggested [14]. It is observed that the classification in the field has no certain definitions related to the differences in a scientific approach. Moreover, two or more concepts can be used together by combining the particular aspects of each façade system.

Interactive façades require human input to initiate a response. It can also be equipped with sensors and an automated building management system that is programmed to optimize the energy consumption of the interior [27]. Moreover, it can be programmed according to different user profiles to enrich the humanspace interaction. According to Fox [28], it can be observed that tangible designs that are used in many architectural spaces owing to the developing technology.

Responsive façades are technologies used in the development of integrated building concepts [29]. The term "responsive" refers to the dynamic building elements that allow the adjustment of the façade to enhance the building's performance requirements. Responsive façades are defined as the mechanisms of the adaptive building which use sensors and actuators to monitor the environment and automate the control of operable building elements [30]. According to Velikov and Thün [27], responsive façades are capable of real-time sensing, climate-adaptive dynamic elements, automation, and user override. Moreover, responsive façades are similar to intelligent façades in terms of being functional and performance-driven. 
Smart façades have the potential to play a significant role in the field of architecture in parallel with developing material technology. Smart surfaces and materials are variable and respond to needs [31]. The smart materials used in performance-driven adaptive building coatings can be provided with electrochromic smart glass [32,33].

Biomimetic façades are adaptive façades based on nature-inspired design. This approach is based on a chosen biological principle but requires an intermediate abstraction phase from the biological principle to the façade [13,34]. Biomimetic façades should react to the changes in the current conditions similar to the reaction of living organisms to the environmental factors. The application of biomimetic approaches to façades contribute the energy efficiency.

Kinetic façades are defined as an architectural form that can be inherently displaceable, deformable, expandable, or capable of movement [35] . They are adjusted efficiently according to boundary conditions such as climatic conditions, different locations, variable functional requirements or emergencies. These façades need an actuating force or a stimulus that triggers the kinetic behavior of the façade modules [31]. Nowadays, it is thought that kinetic architecture will be handled in a different dimension with the use of electromechanical systems.

Advanced and intelligent façades are explained in the following section.

\subsection{Advanced and Intelligent Façades}

An advanced façade is a durable and efficient layer that can respond to climatic conditions that can contribute to the heating, cooling, ventilation, and lighting requirements of a building and increase the comfort of the interior with energy-saving measures. The main difference between advanced and other energy-efficient façade concepts is the implementation of intelligent building elements, monitoring systems and energy systems along with advanced control [29]. Additionally, advanced façades can be assessed under different categories due to the capability of having the combination of different characteristics in an integrated manner within the same façade system.

The term intelligent façade should indicate the sensitivity of a façade to change in the environmental conditions. Buildings equipped with advanced monitoring and control systems [36] are considered as intelligent buildings [37]. Intelligent systems can learn their energy state, thermal structure, and other environmental parameters by combining ambiguous data in information networks and information-based software algorithms. The building management system is the "brain" that has the building decision support system [15]. Kroner stated that the building management system is the central operating unit in which all the information arrives from external sensors, information networks. It defines the appropriate controlled responses of the actuating elements [16]. An intelligent building management system can respond to meteorological changes with the help of sensors and statistical data [36,37]. One of the most important functions is to adjust the temperature, daylight, and humidity values by activating the controllable elements in the façades by using the maximum capacity of passive systems. The decision-making systems of intelligent façades can have restricted or advanced machine-learning.

Primary functions that need to be performed by intelligent systems can be defined as perception, reasoning, and action that corresponds to sensors, control processors, and actuators in electromechanical systems. According to Wigginton and Harris, the environmental goal in the building design should be to strive for building comfort systems, minimizing the initial total energy need by consuming minimal energy to maintain renewable energy sources, current heat gains, and comfort conditions. Ideally, the building itself is a "power station." It is thought that intelligent façades will make contributions to the self-sufficiency of buildings. The amount of energy consumed in buildings mainly depends on the construction, the thermal properties, the climatic characteristics, the hours of use of the building, and the characteristics of the systems used in heating and cooling of the building [15]. Having been designed according to all these parameters of decision-making system, intelligent buildings can work in harmony with their environment to ensure the efficient use of energy [38]. The disadvantages of intelligent façades are the lacking in the evaluation of the current situation and the use of the statistical data in the decision-making process. 
To outline the characteristics of intelligent façade prototypes are examined according to actuator mechanisms, motion types, material systems, and algorithms and software that are used shown in Table 1. When environmental sensors were examined, it was observed that photocell, which can be used as solar sensor and temperature sensor, is common component of the intelligent façades. This means that in all prototypes the priority is the solar effect. Daylight sensors and humidity sensors are also used alongside the solar sensors. A hierarchy between the sensors are observed in which each of these sensors affects the actuator mechanism at different rates and in different ways. When the actuator mechanisms are considered, no common findings have been reached. Each prototype is designed specifically to its environment, function and design problem. In general, two main approaches can be mentioned as motorized actuators, and pneumatic actuators. While motorized actuators are servo and stepper motors and pneumatic actuators are valves and soft systems. Actuators play a crucial role in identifying motion types and patterns. Motion types have a structure that varies according to design and conditions as in actuator mechanisms. When the examples in Table 1 are examined, any common mode of action is not found. While linear, rotation, and solar tracking motions are observed in the motorized actuators, the deflation and inflation motions are observed in systems with pneumatic actuators. Material systems vary according to movement patterns and shape of actuators. Each design is made and applied according to the different material systems. Materials suitable for outdoor use are selected on all façades. When the algorithms and software are examined, the use of Arduino stands out in all cases except the two cases. Arduino is a system that is used in initial prototypes because it is cheap and easy to learn and apply.

Table 1. The case studies of intelligent prototypes

\begin{tabular}{|c|c|c|c|c|c|c|}
\hline Article title/Author(s) & $\begin{array}{l}\text { Module } \\
\text { Name } \\
\end{array}$ & Sensors & $\begin{array}{l}\text { Actuator } \\
\text { Mechanism }\end{array}$ & $\begin{array}{l}\text { Motion } \\
\text { Type } \\
\end{array}$ & $\begin{array}{l}\text { Material } \\
\text { System }\end{array}$ & $\begin{array}{l}\text { Algorithm } \\
\text { /software }\end{array}$ \\
\hline $\begin{array}{l}\text { The Adaptive Solar Façade: } \\
\text { From Concept to Prototypes, } \\
\text { Nagy Z. et al. }[20]\end{array}$ & $\begin{array}{l}\text { Adaptive } \\
\text { Solar } \\
\text { Façade } \\
\text { (ASF) } \\
\text { Module }\end{array}$ & $\begin{array}{l}\text { Temperature, } \\
\text { daylight, } \\
\text { humidity, } \\
\text { photovoltaic, } \\
\text { cells (as sensors) }\end{array}$ & $\begin{array}{l}\text { Soft } \\
\text { pneumatic } \\
\text { silicon } \\
\text { rubber }\end{array}$ & $\begin{array}{l}\text { Rotation } \\
\text { (deflation and } \\
\text { inflation) } \\
\text { solar tracking } \\
\text { behavior }\end{array}$ & $\begin{array}{l}\text { Double } \\
\text { bent and } \\
\text { laser-cut } \\
\text { stainless } \\
\text { steel }\end{array}$ & $\begin{array}{l}\text { Arduino, } \\
\text { EasyVR, } \\
\text { Diva }\end{array}$ \\
\hline $\begin{array}{l}\text { Adaptive Distributed Robotics } \\
\text { for environmental Performance, } \\
\text { Occupant Comfort and } \\
\text { Architectural Expression, } \\
\text { Rossi D. et al [21] }\end{array}$ & $\begin{array}{l}\text { Adaptive } \\
\text { Solar } \\
\text { Envelope } \\
\text { (ASE) }\end{array}$ & $\begin{array}{l}\text { Light sensors, } \\
\text { solar thin film } \\
\text { cell (as } \\
\text { sensors) }\end{array}$ & $\begin{array}{l}\text { Servo } \\
\text { motors }\end{array}$ & $\begin{array}{l}\text { Rotation } \\
\text { (mechanic), } \\
\text { solar tracking } \\
\text { behavior }\end{array}$ & $\begin{array}{l}\text { Solar } \\
\text { thin film } \\
\text { cell }\end{array}$ & $\begin{array}{l}\text { Arduino, } \\
\text { Q-learning }\end{array}$ \\
\hline $\begin{array}{l}\text { Performative Building Skin } \\
\text { Systems: A Morphogenomic } \\
\text { Approach Towards Developing } \\
\text { Real-Time Adaptive Building } \\
\text { Skin Systems, } \\
\text { Biloria N., Sumini V. [22] }\end{array}$ & $\begin{array}{l}\text { The Stomata } \\
\text { Membrane }\end{array}$ & $\begin{array}{l}\text { Temperature, } \\
\text { daylight, } \\
\text { humidity, } \\
\text { wind }\end{array}$ & $\begin{array}{l}\text { Motors and } \\
\text { linear } \\
\text { actuators }\end{array}$ & $\begin{array}{l}\text { Linear motion } \\
\text { (as stomata, Y } \\
\text { axis) }\end{array}$ & $\begin{array}{l}\text { ETFE } \\
\text { sheets, } \\
\text { metal } \\
\text { frame }\end{array}$ & $\begin{array}{l}\text { Generative } \\
\text { component, } \\
\text { Max msp \& } \\
\text { jitter }\end{array}$ \\
\hline $\begin{array}{l}\text { Integrating Physical and Digital } \\
\text { Prototypes Using } \\
\text { Parametric BIM in the Pursuit } \\
\text { of Kinetic Façade, } \\
\text { Mallasi Z. [23] }\end{array}$ & - & $\begin{array}{l}\text { Solar } \\
\text { exposure }\end{array}$ & $\begin{array}{l}\text { Servo } \\
\text { motors and } \\
\text { linear } \\
\text { actuators }\end{array}$ & $\begin{array}{l}\text { Linear } \\
\text { motion, } \\
\text { full rotation }\end{array}$ & $\begin{array}{l}\text { Light } \\
\text { tensile- } \\
\text { fabric, } \\
\text { wood } \\
\text { frame }\end{array}$ & $\begin{array}{l}\text { Revit/API, } \\
\text { Arduino }\end{array}$ \\
\hline $\begin{array}{l}\text { Kinetic Façade Design: } \\
\text { Responsive to Daily sun Paths } \\
\text { to Maximize Shading and } \\
\text { Views, Pacheco, A., Micheli } \\
\text { M., Mull, A. [26] }\end{array}$ & $\begin{array}{l}\text { Kinetic } \\
\text { Façade } \\
\text { System }\end{array}$ & $\begin{array}{l}\text { Digital solar } \\
\text { sensor }\end{array}$ & $\begin{array}{l}\text { Servo } \\
\text { motors }\end{array}$ & $\begin{array}{l}\text { Fabric } \\
\text { oriented } \\
\text { linear motion }\end{array}$ & $\begin{array}{l}\text { Light } \\
\text { tensile- } \\
\text { fabric }\end{array}$ & $\begin{array}{l}\text { Grasshopper } \\
\text {, Ladybug, } \\
\text { Honeybee, } \\
\text { and Firefly }\end{array}$ \\
\hline $\begin{array}{l}\text { Integration of Environmental } \\
\text { Sensors with BIM: case studies } \\
\text { using Arduino, Dynamo, and } \\
\text { the Revit API, } \\
\text { Kensek K.M. [24] }\end{array}$ & - & $\begin{array}{l}\text { Photocell (as } \\
\text { light sensor) }\end{array}$ & $\begin{array}{l}\text { Micro servo } \\
\text { motors }\end{array}$ & $\begin{array}{l}\text { Rotation } 45 \\
\text { degree }\end{array}$ & $\begin{array}{l}\text { Wood } \\
\text { panel }\end{array}$ & $\begin{array}{l}\text { Revit. } \\
\text { Dynamo, } \\
\text { Arduino, } \\
\text { Processing }\end{array}$ \\
\hline $\begin{array}{l}\text { Sunshades } \\
\text { About Designing Adaptable } \\
\text { Solar Façades, Carl T. et al. } \\
{[25]}\end{array}$ & Miuso & Light Sensors & $\begin{array}{l}\text { Pneumatic } \\
\text { valves }\end{array}$ & $\begin{array}{l}\text { Folding } \\
\text { rotation } \\
\text { (deflation and } \\
\text { inflation) }\end{array}$ & $\begin{array}{l}\text { Organic } \\
\text { photo } \\
\text { voltaic } \\
\text { solar } \\
\text { cells } \\
\end{array}$ & $\begin{array}{l}\text { Grasshopper } \\
\text { Arduino, } \\
\text { Solar } \\
\text { Swarm }\end{array}$ \\
\hline
\end{tabular}


When the prototypes are examined, it is observed that the decision-making mechanisms operate the actuators according to the real-time data received via the sensors without no prediction algorithm. All prototypes are found to be directly responsive which is not efficient in convergent situations called critical situations.

\subsection{Design and Decision-making Strategies in Intelligent Façades}

Intelligent façades have different design strategies such as ensuring sustainability and increasing the interaction with the environment and adapting to special climatic conditions [28,37,39]. In order to look at the discussion in more detail, it would be appropriate to highlight a few general strategies in intelligent façades. Being dynamic is the prominent aspect of the intelligent façades. Buildings need to be dynamic in order to react to changes in their environment and to be in harmony with them $[13,36]$. It can be designed either the entire façade dynamically or an element or a component of the façade [40]. It is possible for the intelligent façades to react to stimuli as a performative structure considering its dynamic nature $[41,42]$.

Designing it according to the required needs throughout the life cycle of the building is another important design strategy. Thus, even if the user of the building changes, the façade movements should be designed to adapt to the comfort conditions of the user [43]. Moreover, the intelligent façades should be designed by considering future comfort needs and anticipated climatic changes. This adaptive design approach prepares the ground for the building to contribute to its sustainability and to be permanent [44]. They can adapt in the long term or short terms as seasonal and daytime respectively by allowing a better relationship with the environment and the user [45]. The other design strategy employed in design process is the user comfort. The façades should be designed to be in harmony with their surroundings while prioritizing the comfort of the user [46]. Intelligent façades direct designers to plan the interiors to meet the needs of the user [43]. They perceive the changes around itself through sensors, then they assures the users to be affected positively in these changes [47]. In this way, they ensure that comfort conditions are kept at an optimum level. At the same time, the intelligent façades should be designed to have an interaction with the user to check whether the response is fitted [48]. Lastly, intelligent façades should be compatible with electronic, mechanical or electromechanical, pneumatic, hydraulic and many similar systems either manually or automatically $[49,50]$. They are evaluated according to decision-making types that is able to react effectively to energy conservation and user comfort conditions. The decision-making system analyzes and evaluates the data required for the management of the façade that moves to meet the criteria.

Decision-making mechanism optimizes multiple parameters and manages the façade with advanced algorithms in advanced intelligent façades. Some parameters conflict with each other in the decisionmaking mechanism. These conflicts may causes reduced building energy efficiency. Additionally, various measures are taken to prevent these conflicts. In literature, there are two main reasons of the conflict between parameters of intelligent façade design. First conflict is caused by users demanding different comfort conditions. The second conflict occurs between users and decision-making algorithms [17,51,52]. Also, problems may occur by conflicting parameters. For example, when the amount of outdoor brightness is higher than the comfort conditions, the glass layer is converted into opaque. The opaque glass layer also causes the interior to be deprived of solar radiation and cool down the interior. The fact that the parameters in similar situations affect each other has revealed the necessity to design more efficient decision-making algorithms that control façades.

\section{AN ADVANCED INTELLIGENT FAÇADE (AIF) MODULE}

According to the definitions on the literature, AIF module have different features inherited from different sub-categories of adaptive façades. AIF is an adaptive and advanced module that uses complex high-level algorithms. The brain of the AIF module works as a decision-making used restricted machine learning based on statistical weather data. This module, which uses advanced algorithms, is called AIF because of all these features. Also the AIF module can be characterized as a smart façade thanks to the use of smart materials. In addition, the AIF module can be characterized as a responsive façade because it reacts to the temperature that affects the light level and humidity. It can also be classified as an interactive façade module because the operation of the module depends on the presence of the user. Due to the smart material being 
controlled by the "brain" of the façade, the AIF module can be considered within the scope of intelligent façades. With all these features, the Advanced Intelligent Façade module exhibits the characteristics of adaptive façades.

\begin{tabular}{|c|c|c|c|}
\hline Input & Adaptation Factors & Decision-making Algorithms & Actuators and Layers \\
\hline $\begin{array}{l}\text { Measured Data } \\
\text {-Temperature Level } \\
\text { - Light Level } \\
\text { - Humidity Level * }\end{array}$ & $\begin{array}{l}\text { User Needs } \\
\text { - Comfort Conditions } \\
\text { Environmental Needs } \\
\text { - Energy Efficiency }\end{array}$ & $\begin{array}{l}\text { Priority Algorithm } \\
\text { (For the conflicting parameters) } \\
\text { Critical Decision Algorithm } \\
\text { (For the boundry conditions) }\end{array}$ & $\begin{array}{l}\text { Motorized Systems } \\
\text { - Shutter and Electrochromic } \\
\text { Smart Glass } \\
\text { Response to Temperature; } \\
\text { open-closed }\end{array}$ \\
\hline $\begin{array}{l}\text { Statistical Data } \\
\text { (weather data of the } \\
\text { previous day) }\end{array}$ & $\begin{array}{l}\text { Façade Needs } \\
\text { - Minimizing Material Fatigue }\end{array}$ & $\begin{array}{l}\text { Instant Response } \\
\text {-Precipitation }\end{array}$ & $\begin{array}{l}\text { Electrochromic Systems } \\
\text { - Electrochromic Smart Glass } \\
\text { Response to Light; on-off }\end{array}$ \\
\hline Database & \multicolumn{2}{|c|}{ Decision-making Mechanism } & Actuation \\
\hline
\end{tabular}

Figure 1. The conceptual framework of the AIF module

According to Figure 1, two different inputs are determined as measured data and statistical data in the AIF module. For measured data, temperature, light and humidity level, for statistical data, measurements of the same parameters at the same time interval the day before are determined as inputs. All of these data are stored in the database to be used when needed.

The decision-making mechanism of the AIF module are discussed under two parts as adaptation factors and decision-making mechanism. The first of these adaptation factors are comfort conditions, increasing energy efficiency and minimizing material fatigue due to movement of kinetic components of façade. In this way, the AIF module is designed to respond to user needs, environmental needs and façade needs. The original scientific contribution of this article to academic literature is the conflict solving algorithms that are named critical decision algorithm and priority algorithm. The extensive research in recent intelligent façade prototypes shows that the mainly used data type as input for the decision-making system is ambient data. However, the statistical data is used for the weather forecasts rather than the ambient data. Thus, the conflict encountered in the boundary conditions of decision-making systems is solved with the critical decision algorithm which used the statistical data of the previous day. The developed AIF module is designed as an autonomous and responsive system, which is controlled by a decision-making system that includes conflict solving algorithms.

A rule-based algorithm based on multi-criteria optimization directly controls each layer to increase the efficiency of the façade. Designed using materials that meet different needs in parallel with the developing material technology, the module consists of two layers, blinds and smart glass. In order to compensate for the limitations in providing interior comfort, they can be opened and closed with the help of two layers of motorized systems. The opening and closing of the module is decided by measuring the temperature level. In addition, thanks to the electrochromic systems, the façade can keep the amount of light in the interior at the specified level. Depending on the real time measurement results of the light level, the electrochromic smart glass can be switched on or off position.

The AIF module is an intelligent system that is integrated to the passive façade system in order to balance the statistical data with the ambient data. It means that the façade system is a highly reactive architectural prototype rather than an automation system. In this respect, the proposed module can be defined as a performance-driven rather than a performance-oriented design in terms of adaptive façades. The potential application areas of adaptive façades are developing in parallel with the technological advances. The most important constituents in increasing the potential of adaptive façades can be expressed as the development of decision-making systems and material technology. The advancement in software interfaces that help 
design and production has also become a significant turning point in terms of the applicability of adaptive façades.

\subsection{Digital System: The Brain}

The AIF module is autonomous and performance-driven with multi-objective algorithms, the priority algorithm, and the critical decision algorithm. The AIF module can be reprogrammed according to the spatial needs. In this way, it can be used as a tool in providing various comfort conditions. The adaptation of the AIF module to any climate or function is possible owing to the developed software. The module is designed with a flexible programming system. It can respond to continuous and simultaneous optimization during the operation.

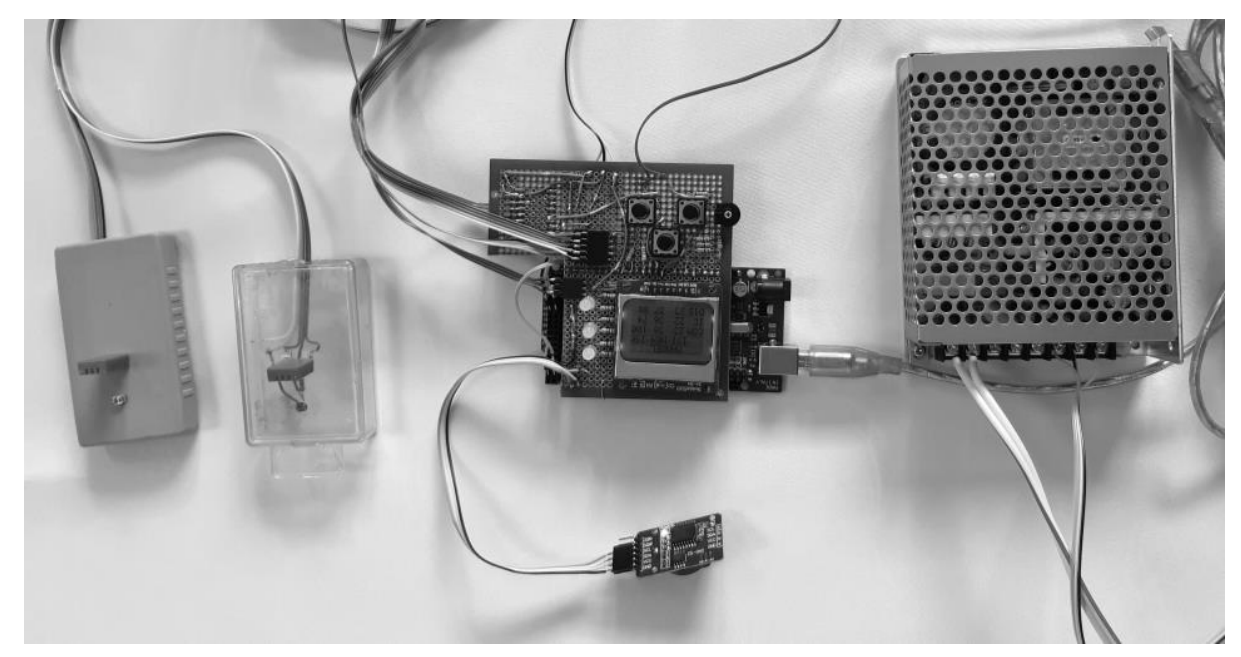

Figure 2. AIF module; "Brain" and the control panel (left to right: sensors, Arduino boards, and microprocessors (below: timer) hard drive and support unit)

Adaptation of the module, according to climatic data is related to the layers. Because of the temperature, light and humidity levels of different climate types, it is expected that the modules for these climate types should have different layers. Especially in regions where daily and seasonal temperature differences are high, it may be necessary to use layers with different physical properties. The AIF module is designed to meet the climatic conditions of the Mediterranean region, where the daily and seasonal temperature differences are relatively low.

The structural details of the module are developed in the physical production phase, and the simulation is completed in the digital environment. The control system is designed using Arduino Mega supported by Arduino Nano (Figure 2) and scripted in $\mathrm{C}++, \mathrm{C}$ Sharp (\#) and Python languages. Arduino Mega is electronic equipment that can process more data than other Arduino chipsets and allows multi parameters in the algorithm. However, due to the complexity of data such as climatic changes, seasonal and daily temperature differences, more data is collected and stored in the brain owing to Arduino Mega.

The operation of the module and the decision-making system is shown in Figure 3. In the developed AIF module, the sensors are designated as primary data sources. In this way, the AIF module can be measured and responded in real-time. Sensors detect the variable states in milliseconds and transmit the data to the system. The transmitted data allow the immediate or periodical response of the decision-making system. For example, in the incident of rain, a liquid-impermeable layer is activated as an instant response. If the temperature falls, the other layers of the module may become active or passive systematically according to the inconsistency of other rules. For example, the reaction of the module is reconfigured occasionally due to the temperature changes at sunrise and sunset. 
Figure 3 shows the $8.6 \mathrm{sp} 2$ version of the Proteus software, where the brain of the AIF module is designed. According to Figure 4, the circuit reacts and activates the servo and stepper motors. According to the results of the circuit diagram, the module works efficiently.

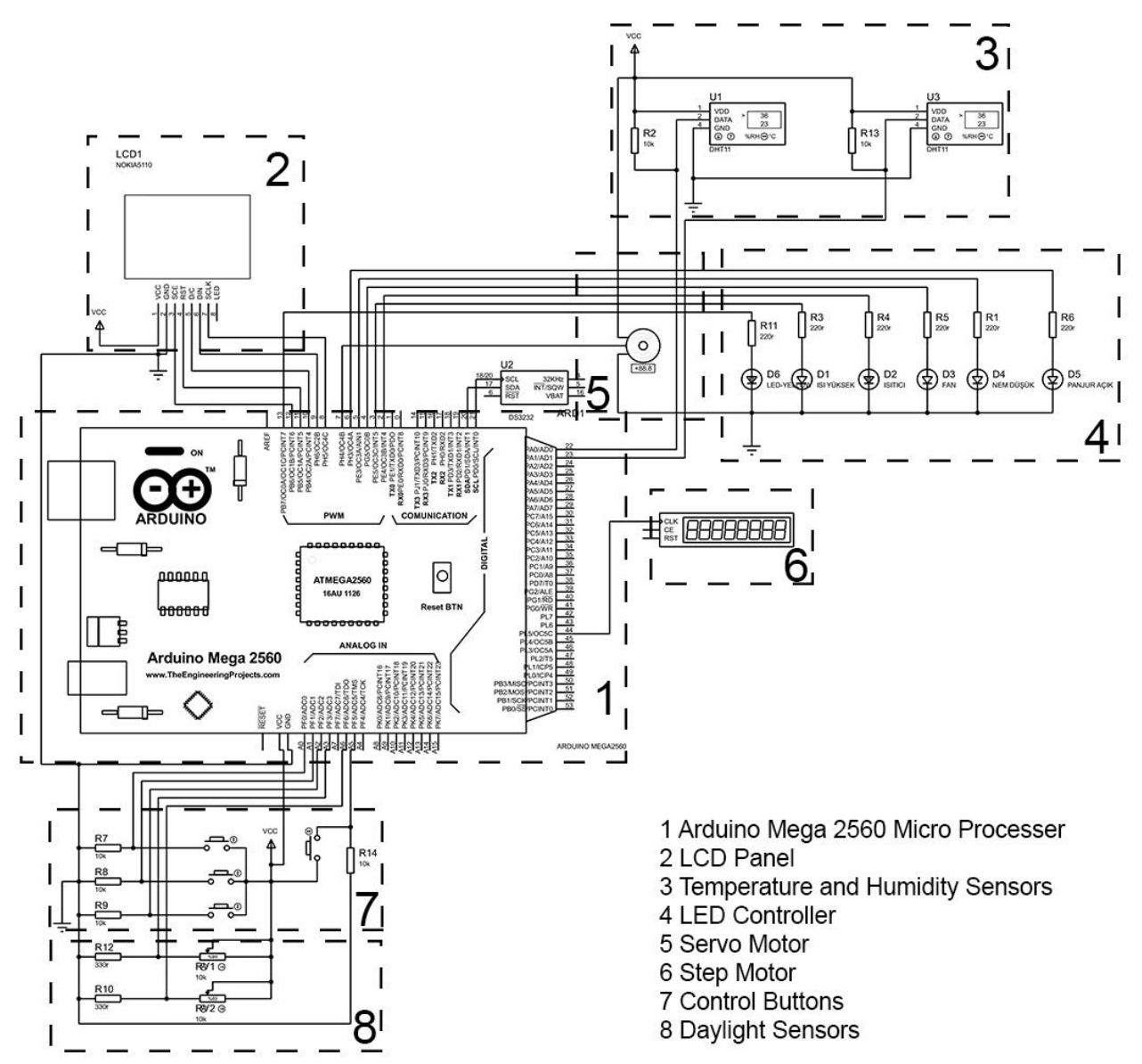

Figure 3. Decision-making system and its parts

The AIF module designed as performance-driven has been developed by Arduino and Proteus. In the current AIF module, the temperature is selected as the priority parameter. Observations and analyses of energy conservation show that energy is mostly consumed to provide heat to the building. Additionally, the temperature is the most crucial parameter in terms of energy conservation in all types of buildings, such as office, residential, and public buildings. The second important parameter of the AIF module is the daylight level due to increased electricity consumption related to the frequent use of artificial lighting at particular times of the day. Therefore, building operating costs are increasing with respects to passive systems. In this way, the daylight level should be set in a narrow range of value for buildings. The third parameter in the AIF module is the humidity of the air. As the limitation of this prototype, humidity sensor was used because of the effect of temperature on felt value. As humidity increases, it is added as a multiplier to the perceived value. In this way, the brain of the module can compute whether the façade is exposed to the precipitation. Additionally, it makes predictions by calculating the temperature of the day before.

The AIF module uses complex algorithms to analyze conflicts in the decision-making process. For this reason, it is necessary to optimize the number of relevant parameters (Figure 4) for the efficient and proper operation of the system. These parameters related to environmental conditions are detected by Arduino's temperature, light, humidity sensors, and displayed instantly. In following, the main processor can process the displayed data according to the priority and critical decision algorithms in the Arduino interface in order to control the servo and stepper motors. 


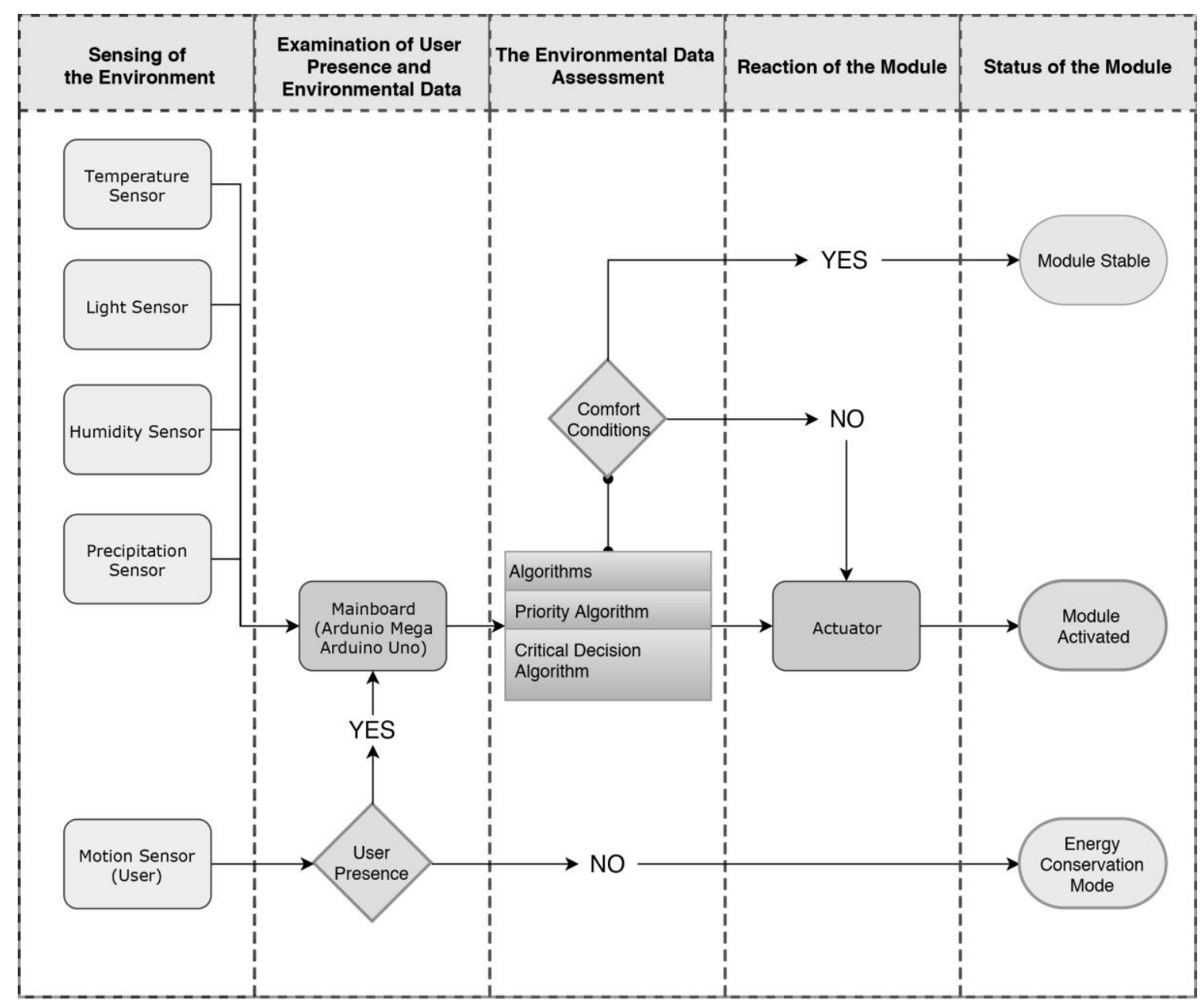

Figure 4. Flowchart of the decision-making system

Multiple parameter optimization is based on the principle of harmonizing various environmental parameters with each other in order to achieve interior comfort conditions. Using multiple layers in an integrated way, assures the efficiency of adaptive façades. Outputs based on different percentage values ensure that the façade adapts to the ambient conditions.

The working principle of the priority algorithm is as follows. If the priority parameter is specified in the command line as temperature, it provides the given range. If the second priority is the daylight level, the software optimizes the light level of the indoor by keeping the temperature level constant within that range. Priority algorithms used for conflict situations are expected to be supported by an optimization algorithm to increase the efficiency of the system.

The response of the façade will not work if the real-time measurements between the given range. In order to maintain the linearity of the algorithm, there must be a difference in daylight value more than twenty lumens and in temperature more than one Celsius degree. The critical decision method will be applied to the system if the input is below these values. A critical decision method is an approach that decides whether there should be a change or response under specific values in kinetic systems.

If the difference between ambient and aimed temperature is below one Celsius degree the critical decision algorithm checks the statistical data of the previous day in order to activate the façade system. By doing so, the system saves energy by keeping the module in the same position. Another conflict occurs where the many parameters are affecting the decision-making system of the intelligent façade. For example, a tradeoff between the temperature and daylight parameters is made by priority algorithm in a system in which 
multi parameters affected. If the temperature is selected as a primary parameter, the daylight levels are optimized as a secondary parameter.

\subsection{Physical System: The Electrochromic Glass and Shutter}

The AIF module is an adaptive multi-layer module based on performance (Figure 5). Performance requirements are provided by two layers with different characteristics. The outermost layer of the façade is a shutter made of translucent crystal polycarbonate. It is able to roll by folding. This layer is available in closed, fully open, and semi-open positions. This layer is responsible for heat protection. Moreover, it has been designed to protect the module from environmental impacts by becoming active in precipitation conditions. The opening and closing mechanism of the shutter layer is moved by the servo and stepper motors.

The second layer is a smart material made of electrochromic glass. This glass can be closed, fully open and semi-open and can become opaque and transparent if necessary. Thus, it ensures the ventilation of the building and the balance of light levels. This layer is controlled by two different mechanisms. The opening and closing mechanism of this layer are controlled by the servo and stepper motors. It is also possible for this opaque and transparent layer to be activated by an electrochromic stimulus. Using smart glass technology, a single façade layer within designed module becomes multi-functional. Moreover, this layer can provide comfort conditions by being controlled by a decision-making algorithm. Using smart glass technology in a single façade layer for different functions can be described as another unique aspect of the AIF module.

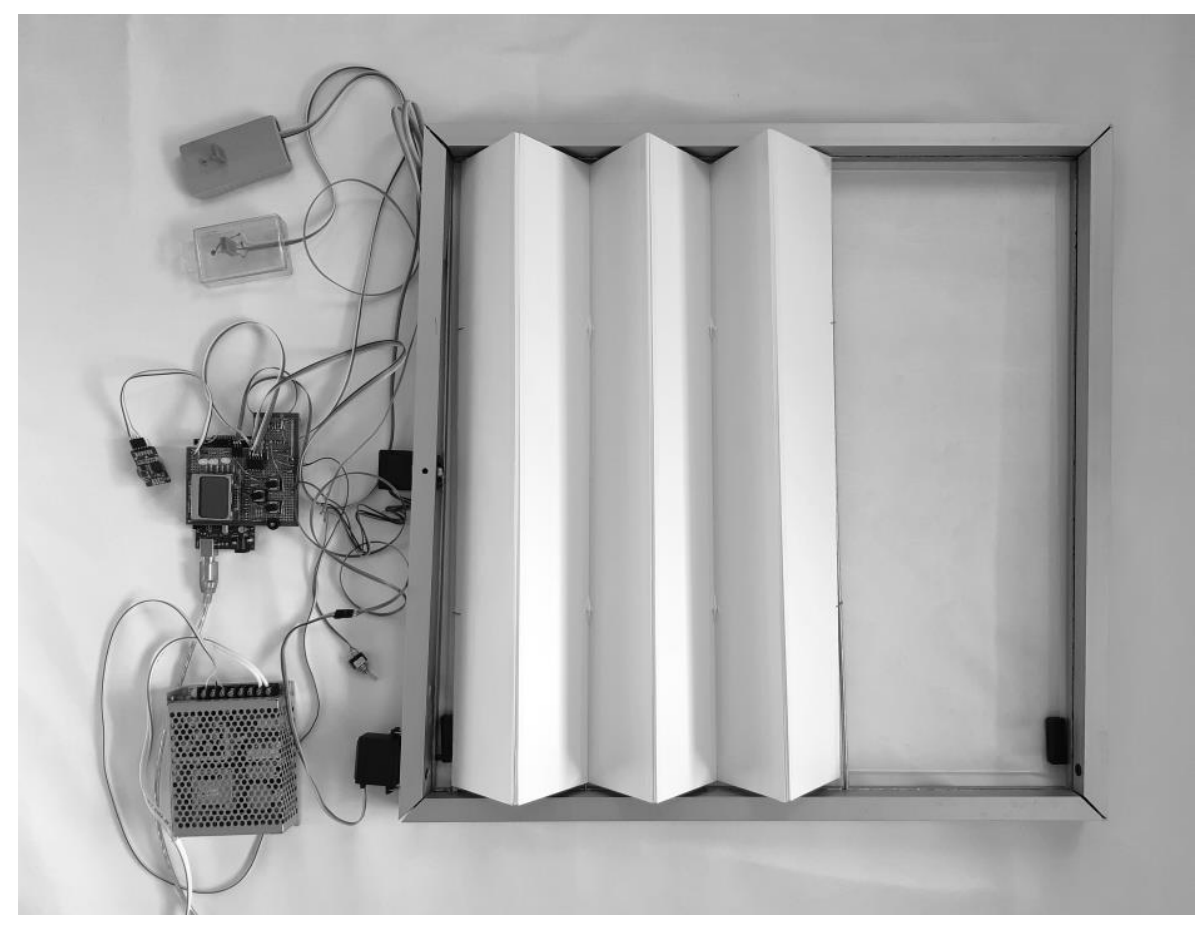

Figure 5. Physical simulation of the AIF Module

Additionally, the interaction sensor is added to the module in order to understand whether the user is in the room. Thus, it is possible to evaluate the façade module as a performance-driven, reactive, and interactive module. In the decision-making component of the module, the statistical data (daily temperature, daylight values, etc.) is used in order to initiate the operation in critical situations. Using statistical data as a complementary source is another aspect of the module. 


\section{SIMULATION OF THE AIF MODULE}

AIF module simulated for performance validation with four different weather scenarios selected in Mediterranean climate. The simulation method is interpreted from the simulation studies in literature $[53,54]$. In this simulation, a space with a ceiling height of three meters, a width of six meters and a depth of six meters is digitally modelled. In this model, a total of fifty AIF modules, designed in $60 \mathrm{~cm} \mathrm{x} 60 \mathrm{~cm}$ dimensions, are placed digitally on the south side of the volume. Other façades of the space are designed as standard and non-permeable walls. The purpose of placing the modules only on the south side is that the thermal radiation of the Mediterranean region is high.

This volume is simulated by integrating climatic data with the help of a script. The statistical data of the previous day and the current outdoor temperature have been implemented into the system. The target temperature is set at 25 degrees Celsius in all scenarios. 1 degree Celsius below and above the aimed temperature is determined as the optimum temperature for the user. In the light of these data, the change in the interior temperature is measured on a façade where the standard and AIF module are used. The standard façade is designed by creating a translucent surface. By means of this simulation, it is aimed to compare the effects of two different façades in terms of interior comfort under different weather conditions. In the tables (Tables 2, 3,4) it can also be observed how the AIF module behaves according to various climatic conditions. Consisting of two different layers, AIF intervenes the temperature by activating the shutter made of translucent crystal polycarbonate and the light level with the electrochromic smart glass layer. In some special situations, the electrochromic glass minimizes thermal radiation by turning itself on by becoming opaque.

Multi-objective optimization is used in the decision-making system of the AIF module (Figure 2). Unlike single optimization, multiple optimization systems allow alternative configurations and various scenarios resulting from conflicting situations. The software is developed to provide the optimum response by evaluating the possible scenarios. According to this, AIF module can be used on the façades of all buildings in the Mediterranean climate.

The constraints of the AIF module and its simulation can be listed as follows;

- In the digital simulation, the thermal values of the materials in the standard façade and intelligent façade in which AIF modules are placed are determined the same and their thicknesses are equal. Therefore, the data in the simulation can be interpreted comparatively.

- The inputs in the simulation phase are determined as those that directly affect the temperature level and light level. Humidity affects the felt air temperature as a multiplier. At the same time, although it is foreseen in the AIF module to move the layers of the façade according to the probability of precipitation, this parameter has been neglected in the simulation in order to minimize the number of parameters.

- In the simulation, acoustic inputs and values are excluded from the evaluation.

- The duration of the simulation is determined as a 24-hour period between 00:00 and 23:00. The module, which includes a user presence sensor, has been enabled to work throughout the day. Thus, it is assumed that a user exists within the space during this period.

- During the simulation process, layers are always open, closed or on-off. These layers can be programmed to be brought to semi-open or slightly open positions to ventilate and improve indoor air quality.

- Location-dependent values such as anthropogenic heat and urban heat islands are excluded from simulation. 
Tables 2, 3, 4 and 5 show hourly simulation results of internal and external temperatures on equinox dates according to weather data taken from open weather data platform ("World Temperatures - Weather Around The World" 2019 [55]). The response of the layers of the AIF module adapted to the changing weather is also included in the tables. In addition, simulation data shows how the indoor temperature changes in comparison with a standard façade.

Table 2 shows the state of the module and the indoor-outdoor temperature balance according to the weather in the September 23 equinox. Accordingly, September 23 can be described as the date on which the AIF module compensates the temperature most effectively compared to the standard façade. It is observed that the indoor temperatures can be adapted in a balanced way with the outdoor temperature. Under these conditions, it is observed that the layers of the AIF module responded regularly and that the critical decision algorithm is used frequently. According to Table 2, a correlation is observed between statistical data and outdoor temperature. This correlation increases the probability that the responses given as a result of the critical decision algorithm in case of boundary conditions are correct. For this reason, although the critical decision algorithm is activated, if the current temperature is not parallel to the temperature change of the day before, the system performs the opposite action and the critical decision algorithm returns to the decision before the applied decision. In this way, the algorithm manages the façade according to the feedback mechanism by comparing the data received from the sensors with the statistical data simultaneously.

Table 2. 23 September 2018 indoor-outdoor, weather data and the layers of AIF

\begin{tabular}{|c|c|c|c|c|c|c|c|c|c|c|c|c|}
\hline & Climatic & Data (Stat & tical dat & 22 Septen & ber 2018 & & & AIF & Iodule & Layers & & \\
\hline & Amb & 1 & data: 2 & eptember & 2018) & & & utter & \begin{tabular}{|l|} 
Elect \\
\end{tabular} & cochron & iic G & lass \\
\hline Hours & Statistical Data & $\begin{array}{l}\text { Outdoor } \\
\text { Temp. }\end{array}$ & $\begin{array}{l}\text { Aimed } \\
\text { Temp. }\end{array}$ & \begin{tabular}{|l} 
Indoor \\
Temp. of \\
Standart \\
Façade \\
\end{tabular} & $\begin{array}{l}\text { Indoor } \\
\text { Temp. } \\
\text { of AIF }\end{array}$ & Weather & Open & Closed & Open & Closed & On & Off \\
\hline 00:00 & 22 & 22 & 25 & 22,0 & 22,0 & Clear & & $\mathrm{x}$ & & $\mathrm{x}$ & & $\mathrm{x}$ \\
\hline 01:00 & 22 & 22 & 25 & 22,0 & 22,0 & Clear & & $\mathrm{x}$ & & $\mathrm{x}$ & & $\mathrm{x}$ \\
\hline 02:00 & 23 & 23 & 25 & 22,2 & 22,5 & Clear & $\mathrm{x}$ & & $\mathrm{x}$ & & & $\mathrm{x}$ \\
\hline 03:00 & 21 & 20 & 25 & 21,8 & 22,1 & Fog & & $\mathrm{x}$ & & $\mathrm{x}$ & $\mathrm{x}$ & \\
\hline 04:00 & 21 & 19 & 25 & 21,4 & 21,8 & Fog & & $\mathrm{x}$ & & $\mathrm{x}$ & $\mathrm{x}$ & \\
\hline 05:00 & 21 & 20 & 25 & 21,2 & 21,6 & Fog & & $\mathrm{x}$ & & $\mathrm{x}$ & $\mathrm{x}$ & \\
\hline 06:00 & 21 & 20 & 25 & 21,1 & 21,5 & Fog & & $\mathrm{x}$ & & $\mathrm{x}$ & $\mathrm{x}$ & \\
\hline 07:00 & 21 & 19 & 25 & 20,8 & 21,2 & Fog & & $\mathrm{x}$ & & $\mathrm{x}$ & $\mathrm{x}$ & \\
\hline 08:00 & 23 & 23 & 25 & 21,4 & 22,4 & Fog & $\mathrm{x}$ & & $\mathrm{x}$ & & $\mathrm{x}$ & \\
\hline 09:00 & 24 & 22 & 25 & 21,6 & 22,2 & Fog & & $\mathrm{x}$ & & $\mathrm{x}$ & $\mathrm{x}$ & \\
\hline $10: 00$ & 24 & 22 & 25 & 21,8 & 22,1 & Passing clouds & & $\mathrm{x}$ & & $\mathrm{x}$ & & $\mathrm{x}$ \\
\hline 11:00 & 25 & 23 & 25 & 22,1 & 22,5 & Passing clouds & $\mathrm{x}$ & & $\mathrm{x}$ & & & $\mathrm{x}$ \\
\hline $12: 00$ & 25 & 24 & 25 & 22,5 & 23,1 & Passing clouds & $\mathrm{x}$ & & $\mathrm{x}$ & & & $\mathrm{x}$ \\
\hline 13:00 & 25 & 23 & 25 & 22,7 & 23,0 & Passing clouds & & $\mathrm{x}$ & & $\mathrm{x}$ & & $\mathrm{x}$ \\
\hline $14: 00$ & 26 & 24 & 25 & 23,0 & 23,5 & Passing clouds & $\mathrm{x}$ & & $\mathrm{x}$ & & & $\mathrm{x}$ \\
\hline $15: 00$ & 28 & 25 & 25 & 23,6 & 24,3 & Passing clouds & $\mathrm{x}$ & & $\mathrm{x}$ & & & $\mathrm{x}$ \\
\hline $16: 00$ & 28 & 26 & 25 & 24,2 & 25,2 & Passing clouds & $\mathrm{x}$ & & $\mathrm{x}$ & & & $\mathrm{x}$ \\
\hline $17: 00$ & 27 & 27 & 25 & 24,6 & 25,6 & Sunny & & $\mathrm{x}$ & & $\mathrm{x}$ & & $\mathrm{x}$ \\
\hline 18:00 & 27 & 26 & 25 & 24,9 & 25,6 & Sunny & & $\mathrm{x}$ & & $\mathrm{x}$ & & $\mathrm{x}$ \\
\hline 19:00 & 24 & 23 & 25 & 24,3 & 25,0 & Passing clouds & & $\mathrm{x}$ & & $\mathrm{x}$ & & $\mathrm{x}$ \\
\hline $20: 00$ & 24 & 23 & 25 & 23,9 & 24,6 & Passing clouds & & $\mathrm{x}$ & & $\mathrm{x}$ & & $\mathrm{x}$ \\
\hline $21: 00$ & 22 & 24 & 25 & 24,0 & 24,5 & Clear & & $\mathrm{x}$ & & $\mathrm{x}$ & & $\mathrm{x}$ \\
\hline $22: 00$ & 22 & 22 & 25 & 23,6 & 24,1 & Passing clouds & & $\mathrm{x}$ & & $\mathrm{x}$ & & $\mathrm{x}$ \\
\hline $23: 00$ & 22 & 22 & 25 & 23,2 & 23,7 & Clear & & $\mathrm{x}$ & & $\mathrm{x}$ & & $\mathrm{x}$ \\
\hline
\end{tabular}


Table 3 shows the state of the module and the indoor-outdoor temperature balance according to the weather in the December 21 equinox. Because the indoor and outdoor temperature differences are very high, the façade cannot obtain passive gains. On this date, electrochromic glass switches on and off according to the weather and balances the amount of light to the interior space.

Table 3. 21 December 2018 indoor-outdoor, weather data and the layers of AIF

\begin{tabular}{|c|c|c|c|c|c|c|c|c|c|c|c|c|}
\hline & Climati & Data $(\mathrm{St}$ & istical d & : 20 Dec & lber 2018 & & & AIF & Modu & Laye & & \\
\hline & & jient weat & er data: & Decembe & 2018) & & & ttter & Elect & ochrol & $\overline{\text { ic } \mathrm{G}}$ & lass \\
\hline Hours & Statistical Data & $\begin{array}{l}\text { Outdoor } \\
\text { Temp. }\end{array}$ & $\begin{array}{l}\text { Aimed } \\
\text { Temp. }\end{array}$ & $\begin{array}{l}\text { Indoor } \\
\text { Temp. of } \\
\text { Standart } \\
\text { Façade } \\
\end{array}$ & $\begin{array}{l}\text { Indoor } \\
\text { Temp. of } \\
\text { AIF }\end{array}$ & Weather & Open & Closed & Open & Closed & On & Off \\
\hline 00:00 & 2 & 5 & 25 & 6 & 6 & Clear & & $\mathrm{x}$ & & $\mathrm{x}$ & & $\mathrm{x}$ \\
\hline 01:00 & 2 & 6 & 25 & 6 & 6 & Passing clouds & & $\mathrm{x}$ & & $\mathrm{x}$ & & $\mathrm{x}$ \\
\hline 02:00 & 2 & 6 & 25 & 6 & 6 & Passing clouds & & $\mathrm{x}$ & & $\mathrm{x}$ & & $\mathrm{x}$ \\
\hline 03:00 & 3 & 6 & 25 & 6 & 6 & Passing clouds & & $\mathrm{x}$ & & $\mathrm{x}$ & & $\mathrm{x}$ \\
\hline 04:00 & 2 & 6 & 25 & 6 & 6 & Passing clouds & & $\mathrm{x}$ & & $\mathrm{x}$ & & $\mathrm{x}$ \\
\hline 05:00 & 2 & 6 & 25 & 6 & 6 & Passing clouds & & $\mathrm{x}$ & & $\mathrm{x}$ & & $\mathrm{x}$ \\
\hline 06:00 & 3 & 6 & 25 & 6 & 6 & Passing clouds & & $\mathrm{x}$ & & $\mathrm{x}$ & & $\mathrm{x}$ \\
\hline 07:00 & 3 & 7 & 25 & 6,4 & 6,4 & Passing clouds & & $\mathrm{x}$ & & $\mathrm{x}$ & & $\mathrm{x}$ \\
\hline 08:00 & 3 & 7 & 25 & 6,6 & 6,6 & Passing clouds & & $\mathrm{x}$ & & $\mathrm{x}$ & & $\mathrm{x}$ \\
\hline 09:00 & 4 & 7 & 25 & 6,8 & 6,8 & Partly Sunny & & $\mathrm{x}$ & & $\mathrm{x}$ & $\mathrm{x}$ & \\
\hline $10: 00$ & 3 & 7 & 25 & 7 & 7 & Partly Sunny & & $\mathrm{x}$ & & $\mathrm{x}$ & $\mathrm{x}$ & \\
\hline 11:00 & 4 & 7 & 25 & 7 & 7 & Partly Sunny & & $\mathrm{x}$ & & $\mathrm{x}$ & $\mathrm{x}$ & \\
\hline $12: 00$ & 4 & 7 & 25 & 7 & 7 & Partly Sunny & & $\mathrm{x}$ & & $\mathrm{x}$ & $\mathrm{x}$ & \\
\hline 13:00 & 4 & 8 & 25 & 7,4 & 7,4 & Partly Sunny & & $\mathrm{x}$ & & $\mathrm{x}$ & $\mathrm{x}$ & \\
\hline $14: 00$ & 4 & 8 & 25 & 7,6 & 7,6 & Partly Sunny & & $\mathrm{x}$ & & $\mathrm{x}$ & $\mathrm{x}$ & \\
\hline $15: 00$ & 5 & 8 & 25 & 7,8 & 7,8 & Partly Sunny & & $\mathrm{x}$ & & $\mathrm{x}$ & $\mathrm{x}$ & \\
\hline $16: 00$ & 5 & 8 & 25 & 8 & 8 & Partly Sunny & & $\mathrm{x}$ & & $\mathrm{x}$ & $\mathrm{x}$ & \\
\hline $17: 00$ & 5 & 8 & 25 & 8 & 8 & Partly Sunny & & $\mathrm{x}$ & & $\mathrm{x}$ & $\mathrm{x}$ & \\
\hline 18:00 & 4 & 7 & 25 & 7,8 & 7,8 & Passing clouds & & $\mathrm{x}$ & & $\mathrm{x}$ & & $\mathrm{x}$ \\
\hline $19: 00$ & 5 & 7 & 25 & 7,6 & 7,6 & Passing clouds & & $\mathrm{x}$ & & $\mathrm{x}$ & & $\mathrm{x}$ \\
\hline 20:00 & 5 & 7 & 25 & 7,4 & 7,4 & Passing clouds & & $\mathrm{x}$ & & $\mathrm{x}$ & & $\mathrm{x}$ \\
\hline 21:00 & 4 & 7 & 25 & 7,2 & 7,2 & Passing clouds & & $\mathrm{x}$ & & $\mathrm{x}$ & & $\mathrm{x}$ \\
\hline 22:00 & 5 & 8 & 25 & 7,4 & 7,4 & Passing clouds & & $\mathrm{x}$ & & $\mathrm{x}$ & & $\mathrm{x}$ \\
\hline 23:00 & 6 & 8 & 25 & 7,6 & 7,6 & Passing clouds & & $\mathrm{x}$ & & $\mathrm{x}$ & & $\mathrm{x}$ \\
\hline
\end{tabular}

According to Table 4, the façade cannot achieve passive energy gains since the difference in indoor and outdoor temperature is very high compared to the weather in the March 21 equinox. Since the weather is stable at that time, the AIF module acted as a standard façade module. In this respect, the AIF module is found to be the most inefficient among the examined dates. 
Table 4. 21 March 2019 indoor-outdoor, weather data and the layers of AIF

\begin{tabular}{|c|c|c|c|c|c|c|c|c|c|c|c|c|}
\hline & Clima & Data (St: & tistical & data: $20 \mathrm{I}$ & March 2 & 019 & & & Modul & Layers & & \\
\hline & & weat & her data & a: 21 Mar & ch 2019) & & & utter & & trochrol & Gla: & \\
\hline Hours & $\begin{array}{l}\text { Statistical } \\
\text { Data }\end{array}$ & $\begin{array}{l}\text { Outdoor } \\
\text { Temp. }\end{array}$ & $\begin{array}{l}\text { Aimed } \\
\text { Temp. }\end{array}$ & \begin{tabular}{|l} 
Indoor \\
Temp. \\
of \\
Standart \\
Façade \\
\end{tabular} & $\begin{array}{l}\text { Indoor } \\
\text { Temp. } \\
\text { of AIF }\end{array}$ & Weather & Open & Closed & Open & Closed & On & Off \\
\hline 00:00 & 13 & 9 & 25 & 9 & 9 & Clear & & $\mathrm{x}$ & & $\mathrm{x}$ & & $\mathrm{x}$ \\
\hline 01:00 & 12 & 9 & 25 & 9 & 9 & Passing clouds & & $\mathrm{x}$ & & $\mathrm{x}$ & & $\mathrm{x}$ \\
\hline 02:00 & 12 & 9 & 25 & 9 & 9 & Passing clouds & & $\mathrm{x}$ & & $\mathrm{x}$ & & $\mathrm{x}$ \\
\hline 03:00 & 12 & 8 & 25 & 8,6 & 8,6 & Passing clouds & & $\mathrm{x}$ & & $\mathrm{x}$ & & $\mathrm{x}$ \\
\hline 04:00 & 10 & 9 & 25 & 8,8 & 8,8 & Passing clouds & & $\mathrm{x}$ & & $\mathrm{x}$ & & $\mathrm{x}$ \\
\hline 05:00 & 10 & 9 & 25 & 9 & 9 & Passing clouds & & $\mathrm{x}$ & & $\mathrm{x}$ & & $\mathrm{x}$ \\
\hline 06:00 & 10 & 9 & 25 & 9 & 9 & Passing clouds & & $\mathrm{x}$ & & $\mathrm{x}$ & & $\mathrm{x}$ \\
\hline 07:00 & 10 & 9 & 25 & 9 & 9 & Broken clouds & & $\mathrm{x}$ & & $\mathrm{x}$ & & $\mathrm{x}$ \\
\hline 08:00 & 10 & 10 & 25 & 9,2 & 9,2 & Broken clouds & & $\mathrm{x}$ & & $\mathrm{x}$ & & $\mathrm{x}$ \\
\hline 09:00 & 12 & 11 & 25 & 9,6 & 9,6 & Broken clouds & & $\mathrm{x}$ & & $\mathrm{x}$ & & $\mathrm{x}$ \\
\hline 10:00 & 12 & 10 & 25 & 10 & 10 & Broken clouds & & $\mathrm{x}$ & & $\mathrm{x}$ & & $\mathrm{x}$ \\
\hline 11:00 & 12 & 11 & 25 & 10,2 & 10,2 & Broken clouds & & $\mathrm{x}$ & & $\mathrm{x}$ & & $\mathrm{x}$ \\
\hline $12: 00$ & 12 & 11 & 25 & 10,4 & 10,4 & Broken clouds & & $\mathrm{x}$ & & $\mathrm{x}$ & & $\mathrm{x}$ \\
\hline $13: 00$ & 12 & 12 & 25 & 10,8 & 10,8 & Broken clouds & & $\mathrm{x}$ & & $\mathrm{x}$ & & $\mathrm{x}$ \\
\hline $14: 00$ & 12 & 12 & 25 & 11,2 & 11,2 & Broken clouds & & $\mathrm{x}$ & & $\mathrm{x}$ & & $\mathrm{x}$ \\
\hline $15: 00$ & 13 & 12 & 25 & 11,4 & 11,4 & Broken clouds & & $\mathrm{x}$ & & $\mathrm{x}$ & & $\mathrm{x}$ \\
\hline $16: 00$ & 12 & 11 & 25 & 11,2 & 11,2 & Broken clouds & & $\mathrm{x}$ & & $\mathrm{x}$ & & $\mathrm{x}$ \\
\hline $17: 00$ & 11 & 10 & 25 & 10,8 & 10,8 & Broken clouds & & $\mathrm{x}$ & & $\mathrm{x}$ & & $\mathrm{x}$ \\
\hline 18:00 & 10 & 10 & 25 & 10,6 & 10,6 & Partly Sunny & & $\mathrm{x}$ & & $\mathrm{x}$ & $\mathrm{x}$ & \\
\hline 19:00 & 10 & 10 & 25 & 10,4 & 10,4 & Passing clouds & & $\mathrm{x}$ & & $\mathrm{x}$ & & $\mathrm{x}$ \\
\hline $20: 00$ & 9 & 10 & 25 & 10,2 & 10,2 & Passing clouds & & $\mathrm{x}$ & & $\mathrm{x}$ & & $\mathrm{x}$ \\
\hline $21: 00$ & 9 & 9 & 25 & 9,8 & 9,8 & Passing clouds & & $\mathrm{x}$ & & $\mathrm{x}$ & & $\mathrm{x}$ \\
\hline $22: 00$ & 9 & 9 & 25 & 9,6 & 9,6 & Clear & & $\mathrm{x}$ & & $\mathrm{x}$ & & $\mathrm{x}$ \\
\hline 23:00 & 9 & 8 & 25 & 9 & 9 & Clear & & $\mathrm{x}$ & & $\mathrm{x}$ & & $\mathrm{x}$ \\
\hline
\end{tabular}

Table 5 shows the state of the module and the indoor-outdoor temperature balance according to the weather in the July 21 equinox. Compared to the standard module, the AIF module can be described as the second date in which it compensates most effectively. It is observed that the AIF module can passively be controlled internally and externally in a balanced manner. Under these conditions, it is observed that the layers of the AIF module respond regularly and this is the second date when the critical decision algorithm is used the most. This date can be considered as the time period in which the priority algorithm is used the most. 
Table 5. 21 July 2019 indoor-outdoor, weather data and the layers of AIF

\begin{tabular}{|c|c|c|c|c|c|c|c|c|c|c|c|c|}
\hline & Clin & atic Data (S & Statistica & I data: $20 \mathrm{~J}$ & July 2019 & & & AIF & Module & Layers & & \\
\hline & & mbient we & ather da & ta: 21 July & 2019) & & & utter & Elec & trochrom & c Gl & \\
\hline Hours & $\begin{array}{l}\text { Statistical } \\
\text { data }\end{array}$ & $\begin{array}{l}\text { Outdoor } \\
\text { Temp. }\end{array}$ & $\begin{array}{l}\text { Aimed } \\
\text { Temp. }\end{array}$ & $\begin{array}{l}\text { Indoor } \\
\text { Temp. } \\
\text { of } \\
\text { Standart } \\
\text { Façade }\end{array}$ & $\begin{array}{l}\text { Indoor } \\
\text { Temp. } \\
\text { of AIF }\end{array}$ & Weather & Open & Closed & Open & Closed & On & Off \\
\hline 00:00 & 24 & 24 & 25 & 24 & 24 & Clear & $\mathrm{x}$ & & $\mathrm{x}$ & & & $\mathrm{x}$ \\
\hline 01:00 & 24 & 24 & 25 & 24 & 24 & Clear & $\mathrm{x}$ & & $\mathrm{x}$ & & & $\mathrm{x}$ \\
\hline 02:00 & 23 & 23 & 25 & 23,6 & 23,6 & Passing clouds & & $\mathrm{x}$ & & $\mathrm{x}$ & & $\mathrm{x}$ \\
\hline 03:00 & 23 & 23 & 25 & 23,2 & 23,2 & Clear & & $\mathrm{x}$ & & $\mathrm{x}$ & & $\mathrm{x}$ \\
\hline 04:00 & 23 & 23 & 25 & 23 & 23 & Passing clouds & & $\mathrm{x}$ & & $\mathrm{x}$ & & $\mathrm{x}$ \\
\hline 05:00 & 22 & 23 & 25 & 23 & 23 & Passing clouds & & $\mathrm{x}$ & & $\mathrm{x}$ & & $\mathrm{x}$ \\
\hline 06:00 & 23 & 23 & 25 & 23 & 23 & scattered clouds & & $\mathrm{x}$ & & $\mathrm{x}$ & & $\mathrm{x}$ \\
\hline 07:00 & 24 & 24 & 25 & 23,4 & 23,4 & scattered clouds & & $\mathrm{x}$ & & $\mathrm{x}$ & & $\mathrm{x}$ \\
\hline 08:00 & 25 & 25 & 25 & 24 & 24 & scattered clouds & $\mathrm{x}$ & & $\mathrm{x}$ & & & $\mathrm{x}$ \\
\hline 09:00 & 26 & 27 & 25 & 24,4 & 25,2 & scattered clouds & & $\mathrm{x}$ & & $\mathrm{x}$ & & $\mathrm{x}$ \\
\hline $10: 00$ & 27 & 28 & 25 & 24,8 & 25,6 & Partly sunny & & $\mathrm{x}$ & & $\mathrm{x}$ & $\mathrm{x}$ & \\
\hline $11: 00$ & 28 & 28 & 25 & 25,2 & 26 & Partly sunny & & $\mathrm{x}$ & & $\mathrm{x}$ & $\mathrm{x}$ & \\
\hline $12: 00$ & 29 & 29 & 25 & 25,4 & 26,2 & Partly sunny & & $\mathrm{x}$ & & $\mathrm{x}$ & $\mathrm{x}$ & \\
\hline $13: 00$ & 29 & 30 & 25 & 25,6 & 26,4 & Passing clouds & & $\mathrm{x}$ & & $\mathrm{x}$ & & $\mathrm{x}$ \\
\hline $14: 00$ & 29 & 30 & 25 & 25,8 & 26,6 & Passing clouds & & $\mathrm{x}$ & & $\mathrm{x}$ & & $\mathrm{x}$ \\
\hline $15: 00$ & 29 & 30 & 25 & 26 & 26,8 & Passing clouds & & $\mathrm{x}$ & & $\mathrm{x}$ & & $\mathrm{x}$ \\
\hline $16: 00$ & 29 & 30 & 25 & 26,4 & 27,2 & Passing clouds & & $\mathrm{x}$ & & $\mathrm{x}$ & & $\mathrm{x}$ \\
\hline $17: 00$ & 29 & 29 & 25 & 26,6 & 27,4 & Passing clouds & & $\mathrm{x}$ & & $\mathrm{x}$ & & $\mathrm{x}$ \\
\hline 18:00 & 27 & 28 & 25 & 26,8 & 27,6 & Partly sunny & & $\mathrm{x}$ & & $\mathrm{x}$ & $\mathrm{x}$ & \\
\hline 19:00 & 26 & 28 & 25 & 27 & 27,7 & Partly sunny & & $\mathrm{x}$ & & $\mathrm{x}$ & $\mathrm{x}$ & \\
\hline $20: 00$ & 26 & 26 & 25 & 26,4 & 26,4 & Passing clouds & $\mathrm{x}$ & & $\mathrm{x}$ & & & $\mathrm{x}$ \\
\hline $21: 00$ & 25 & 26 & 25 & 26,2 & 26,1 & Passing clouds & $\mathrm{x}$ & & $\mathrm{x}$ & & & $\mathrm{x}$ \\
\hline $22: 00$ & 25 & 25 & 25 & 25,8 & 25,7 & Clear & $\mathrm{x}$ & & $\mathrm{x}$ & & & $\mathrm{x}$ \\
\hline $23: 00$ & 24 & 25 & 25 & 25,6 & 25,2 & Clear & $\mathrm{x}$ & & $\mathrm{x}$ & & & $\mathrm{x}$ \\
\hline
\end{tabular}

The quantity and physical properties of the AIF module must be modified relative to the direction and orientation of the façade. For example, adding a composite layer consisting of sunscreens to the southern façade is a design decision according to the sun's movement. Because the AIF module is a prototype, it is not designed specifically for a façade orientation, and it can be described as an experimental study to prevent the conflicts of the façade modules in the decision-making phase. The AIF module is designed according to the minimum number of layers to avoid conflicts in decision-making. The relations of these layers with each other are defined in the module's algorithms. Thanks to sensing of the electro-mechanic system, the indoor temperature is convergent to the aimed temperature (25 Celsius) in use of AIF module comparing to the standard façade.

The following results are obtained by evaluating the simulation results in Tables 2, 3, 4 and 5;

- According to simulation studies, the AIF module can be more effective than standard façade modules in providing indoor comfort in the temperature range above 25 degrees Celsius, which is the target temperature in the simulation with 20 degrees Celsius.

- Although the energy efficiency of the AIF module does not always seem possible to provide user comfort within the temperature ranges specified in the simulations, it is predicted that it will contribute to reducing 
the load on active systems (heating and ventilating and air conditioning), especially in situations that vary in certain temperature ranges.

- AIF module is a prototype designed to provide maximum comfort and energy efficiency with minimum movement of façade components. In case of temperature changes that the user cannot feel, the façade maintains its condition and the movement is minimized, ensuring a longer service life of the façade.

\section{CONCLUSION}

In this article, it is aimed to develop a physical prototype named the AIF module and a novel decisionmaking strategy including critical and priority algorithms based on statistical data to solve conflicts in decision-making process in the advanced and intelligent façades. This strategy embedded to an electromechanical prototype is evaluated via four scenarios specific to Mediterranean climate conducted in the digital medium by comparing the outcomes with the static façade. According to all these evaluations, the proposed strategy is considered as an efficient and performative alternative to be used in Mediterranean climate. The AIF module is being more effective at temperature between 20-25 plus degrees Celsius. In comparison to the standard façade, the AIF module is more efficient in terms of enhancing the user comfort by sustaining the ideal indoor temperature in the conflict conditions occurring the sunrise and sunset, which the difference between indoor and outdoor temperature is high.

The contribution of the AIF module to the energy efficiency is to minimizing the use of heating and ventilating and air conditioning systems by preserving the state of the module by using the prediction algorithms. The minimization of the movement of the façade module further enhance the service life of the façade by hampering the system failure due to the material fatigue. The operation method proposed for advanced and intelligent façades is a significance of the paper, which is lacking in the literature as solving conflicts in multi-objective optimization of decision-making process.

The improvement potentials can be listed by applying following concepts to the AIF module embedded decision-making strategy:

- $\quad$ Customization of layers of the AIF module according to the user demand and climate conditions;

- Customization of input parameters according to performance requirements;

- Implementation of weather forecast data retrieved from meteorological stations via internet connection;

- Integration of intelligent building management systems to work with heating and ventilating and air conditioning systems.

Although the adaptive façades have "higher investment, maintenance and/or failure costs" [5], the advanced and intelligent façades as a sub-category of adaptive façades will gain importance in building and construction field considering the rapid adaptation capacity of control mechanisms to newly introduced problems and challenges triggered by climate change. Especially for compensating the effect of built environment to the climate change as a source of anthropogenic heat, adaptive and intelligent strategies as well as components are further developed as a means of creating sustainable built environment.

\section{CONFLICTS OF INTEREST}

No conflict of interest was declared by the authors. 


\section{REFERENCES}

[1] Fricke, E., Schulz, A.P., "Design for changeability (DfC): Principles to enable changes in systems throughout their entire lifecycle", Systems Engineering, (2005).

[2] Crawley, E., De Weck, O., Eppinger, S., Magee, C., Moses, J., Seering, W., Schindall, J., Wallace, D., Whitney, D., "Engineering systems monograph", Massachusetts Institute of Technology, Technical Report, (2004).

[3] Negroponte, N., "Soft architecture machines”, MIT press Cambridge, MA; (1975).

[4] Güzelci, O., Alaçam, S., Kocabay, S., Akkuyu, E., "Adaptability of primary and middle schools to post-pandemic reuse - a discussion in the context of flexibility", Journal of Design Studio, 2(2): 5-22, (2020).

[5] Loonen, R.C.G.M., Trčka, M., Cóstola, D., Hensen, J.L.M., "Climate adaptive building shells: Stateof-the-art and future challenges", Renewable and Sustainable Energy Reviews, 25: 483-493, (2013).

[6] Foged, I.W., Kirkegaard, P.H., “Adaptive architectural envelope”, In: Energy Forum - Solar Building Skins Economic Forum; 105-113, (2010).

[7] De Boer, B., Ruijg, G.J., Loonen, R.C.G.M, Trčka, M., Hensen, J.L.M., Kornaat, W., "Climate adaptive building shells for the future - optimization with an inverse modelling approach", In conference; Energy efficiency first: The foundation of a low-carbon society, Italy, (2011).

[8] Aelenei, D., Aelenei, L., Vieira, C.P., "Adaptive façade: concept, applications, research questions", Energy Procedia, 91: 269-275, (2016).

[9] Attia, S., Garat, S., Cools, M., "Development and validation of a survey for well-being and interaction assessment by occupants in office buildings with adaptive façades", Building and Environment, 157: 268-76, (2019).

[10] Attia, S., Lioure, R., Declaude, Q., "Future trends and main concepts of adaptive façade systems. Energy Science \& Engineering”, 8(9): 3255-3272, (2020).

[11] Johnsen, K., Winther, F.V., "Dynamic façades, the smart way of meeting the energy requirements", Energy Procedia, 78: 1568-1573, (2015).

[12] Barozzi, M., Lienhard, J., Zanelli, A. and Monticelli, C., "The Sustainability of Adaptive Envelopes: Developments of Kinetic Architecture", Procedia Engineering, 155: 275-284, (2016).

[13] Loonen, R., Rico-Martinez, J.M., Favoino, F., Marcin, B., Menezo, C., La Ferla, G., Aelenei, L., "Design for façade adaptability-Towards a unified and systematic characterization". In: Proceeding 10th Energy Forum-Advanced Building Skins, Bern, Switzerland, 1: 1274-84, (2015).

[14] Romano, R., Aelenei, L., Aelenei, D., Mazzucchelli, E.S., "What is an adaptive façade? Analysis of recent terms and definitions from an international perspective", Journal of Façade Design and Engineering, 31: 65-76, (2018).

[15] Wigginton, M., Harris, J., “Intelligent skins”, Routledge, (2002).

[16] Kroner, W.M., "An intelligent and responsive architecture", Automation in Construction, 6 (5-6): 381-93, (1997). 
[17] Luna-Navarro, A., Loonen, R.C.G.M., Juaristi, M., Monge-Barrio, A., Attia, S., Overend, M., "Occupant-Façade interaction: a review and classification scheme", Building and Environment, 177: 106880, (2020).

[18] Böke, J., Knaack, U., Hemmerling, M., "State-of-the-art of intelligent building envelopes in the context of intelligent technical systems", Intelligent Buildings International, 11(1): 27-45, (2019).

[19] Moloney, J., "Designing Kinetics for Architectural Façades: State Change”, Taylor \& Francis, (2011).

[20] Nagy, Z., Svetozarevic, B., Jayathissa, P., Begle, M., Hofer, J., Lydon, G., Willmann, A., Schlueter, A., "The Adaptive Solar Façade: From concept to prototypes", Frontiers of Architectural Research, 5(2): 143-56, (2016).

[21] Rossi, D., Nagy, Z., Schlueter, A., “Adaptive Distributed Robotics for Environmental Performance, Occupant Comfort and Architectural Expression", International Journal of Architectural Computing, 10(3): 341-59, (2012).

[22] Biloria, N., Sumini, V., "Performative building skin systems: a morphogenomic approach towards developing real-time adaptive building skin systems", International Journal of Architectural Computing, 7(4): 643-75, (2009).

[23] Mallasi, Z., "Integrating physical and digital prototypes using parametric BIM in the pursuit of kinetic façade", Parametricism Vs. Materialism: Evolution of Digital Technologies for Development, 8th ASCAAD Conference Proceedings, London, 155-68, (2016).

[24] Kensek, K.M., "Integration of environmental sensors with BIM: case studies using Arduino, Dynamo, and the Revit API", Informes de la Construccion, 30: 66(536), (2014).

[25] Carl, T., Schein, M., Stepper, F., "Sun shades-about designing adaptable solar façades", Sharing Computational Knowledge! - Proceedings of the 35th eCAADe Conference, Sapienza University of Rome, Italy, 2: 165-74, (2017).

[26] https://www.youtube.com/watch?v=ezLViGefm2w\&ab_channel=AnthonyLeeMull Access date: 10.01.2020.

[27] Velikov, K., Thün, G., "Responsive building envelopes: characteristics and evolving paradigms" Trubiano, Design and Construction of High-Performance Homes, 5: 75-92, (2013).

[28] Fox, M., "Interactive Architecture: Adaptive World" Chronicle Books, (2016).

[29] Van der Aa, A., Heiselberg, P., Perino, M., "Designing with Responsive Building Elements", Aalborg University, Aalborg, Denmark, (2011).

[30] Meagher, M., "Designing for change: The poetic potential of responsive architecture". Frontiers of Architectural Research, 4(2): 159-65, (2015).

[31] Fox, M.A., Yeh, B.P., "Intelligent kinetic systems in architecture, in: Managing interactions in smart environments", Springer, 91-103, (2000).

[32] Fernandes, L.L., Lee, E.S., Ward, G., "Lighting energy savings potential of split-pane electrochromic windows controlled for daylighting with visual Comfort", Energy and Buildings, 61: 8-20, (2013).

[33] Lee, E.S., Fernandes, L.L., Goudey, C.H., Jonsson, C.J., Curcija, D.C., Pang, X., DiBartolomeo, D., Hoffmann, S., "A pilot demonstration of electrochromic and thermochromic windows in the Denver Federal Center”, Building 41, Denver, Colorado, (2013). 
[34] Eldin, N.N., Abdou, A., Elgawad, I.A., "Biomimetic potentials for building envelope adaptation in Egypt", Procedia Environmental Sciences, 34: 375-86, (2016).

[35] Zuk, W., Clark, R.H., "Kinetic Architecture”, Van Nostrand Reinhold, (1970).

[36] Clements-Croome, D., Croome, D.J., "Building Environment, Architecture and People. Intelligent Buildings: Design, Management and Operation”, Thomas Telford, (2004).

[37] Ghaffarianhoseini, A., Berardi, U., Al Waer, H., Chang, S., Halawa, E., Ghaffarianhoseini, A., Clements- Croome, D., "What is an intelligent building? Analysis of recent interpretations from an international perspective", Architectural Science Review, 59(5): 338-57, (2016).

[38] Masri, Y., "Intelligent Building Envelopes: Design and Applications", In: The International Conference on Building Envelope Design and Technology, Graz Advanced Building Skins, 37-46, (2015).

[39] Struck, C., Almeida, M., Silva, S., Mateus, R., Lemarchand, P., Petrovski, A., Rabenseifer, R., Wansdronk, R., Wellershoff, F., De Wit, J., Adaptive façade systems - review of performance requirements, design approaches, use cases and market Needs,10th Energy Forum on Advanced Building Skins, (2015).

[40] Kolarevic, B., Parlac, V., editors, "Building dynamics: exploring architecture of change". London; New York: Routledge, (2015).

[41] Hammad, F., Abu-Hijleh, B., "The energy savings potential of using dynamic external louvers in an office building", Energy and Buildings, 42(10): 1888-1895, (2010).

[42] Wang, J., Beltrán, L. O. and Kim, J., "From Static to Kinetic: A Review of Acclimated Kinetic Building Envelopes", In: The Solar Conference, 5: 4022-4029, (2012).

[43] Azar, E., O’Brien, W., Carlucci, S., Hong, T., Sonta, A., Kim, J., Andargie, M.S., Abuimara, T., El Asmar, M., Jain, R. K., Ouf, M. M., Tahmasebi, F., Zhou, J., "Simulation-aided occupant-centric building design: A critical review of tools, methods, and applications", Energy and Buildings, 224 : 110292, (2020).

[44] Grobman, Y.J., Yekutiel, T.P., "Autonomous movement of kinetic cladding components in building façades”, In: Chakrabarti A., Prakash R. (eds) ICoRD'13, Lecture Notes in Mechanical Engineering. 1051-1061, Springer, (2013).

[45] Agee, P., Gao, X., Paige, F., McCoy, A., Kleiner, B., "A human-centred approach to smart housing”, Building Research \& Information, 1-16, (2020).

[46] Tabadkani, S., Roetzel, A., Li, H.X., Tsangrassoulis, A., "A review of automatic control strategies based on simulations for adaptive façades", Building and Environment, 175: 1-19, (2020).

[47] Gupta, S.K., Atkinson, S., O’Boyle, I., Drogo, J., Kar, K., Mishra, S., Wen, J. T., "BEES: Real-time occupant feedback and environmental learning framework for collaborative thermal management in multi-zone, multi-occupant buildings", Energy and Buildings, 125: 142-52, (2016).

[48] Park, J.Y., Ouf, M.M., Gunay, B., Peng, Y., O’Brien, W., Kjærgaard M.B., Nagy, Z., “A critical review of field implementations of occupant-centric building controls", Building and Environment, 165: 106351, (2019). 
[49] Harry, S., "Dynamic Adaptive Building Envelopes - an Innovative and State-of-The-Art Technology" Creative Space, 4;3(2): 167-84, (2016).

[50] Heidari Matin, N., Eydgahi, A., "Technologies used in responsive façade systems: a comparative study", Intelligent Buildings International, 1-20, (2019).

[51] Attia, S., Garat, S., Cools, M., "Development and validation of a survey for well-being and interaction assessment by occupants in office buildings with adaptive façades", Building and Environment, 157: 268-76, (2019).

[52] Attia, S., Navarro, A.L., Juaristi, M., Monge-Barrio, A., Gosztonyi, S., Al-Doughmi, Z., "PostOccupancy Evaluation for Adaptive Façades", Journal of Facade Design and Engineering, 21: 1-9, (2018).

[53] Kensek, K., Hansanuwat, R., "Environment Control Systems for Sustainable Design: A Methodology for Testing, Simulating and Comparing Kinetic Façade Systems", Journal of Creative Sustainable Architecture \& Built Environment, 1: 1, (2011).

[54] Loonen, R.C.G.M., Favoino, F., Hensen J.L.M., Overend, M., "Review of current status, requirements and opportunities for building performance simulation of adaptive façades", Journal of Building Performance Simulation, 4; 10(2): 205-223, (2017).

[55] https://www.timeanddate.com/weather/ Access date: 10.01.2020. 